\title{
THE ADVENT OF CHILD RIGHTS ON THE INTERNATIONAL SCENE AND THE ROLE OF THE SAVE THE CHILDREN INTERNATIONAL UNION 1920-45
}

\author{
Lara Bolzman*
}

The Save the Children International Union (SCIU) was founded in 1920 in Geneva by the Save the Children Fund of London in cooperation with the Comite International de Secours aux Enfants of Bern. This philanthropic organization was created in the interwar context. The Declaration of Children's Rights, written in 1923 by the Union, is certainly the most important work of the SCIU. Adopted in 1924 by the General Assembly of the League of Nations, this statement marks the entry of the child into international relations. Moreover, the Declaration reveals the evolving legal status of the child. At times an innocent victim, at other times perceived as an "abnormality", the notion of childhood is in constant evolution. What this stage of life really represents depends on the way it is viewed by society, by politics, by institutions and organizations, etc.

\section{Introduction}

The Save the Children International Union (SCIU) was founded in 1920 in Geneva by the Save the Children Fund of London in cooperation with the Comite International de Secours aux Enfants of Bern and under the patronage of the International Red Cross Committee (ICRC). Created at the same time as the League of Nations (the League), ${ }^{1}$ the SCIU contributed to the development and the name of Geneva as an international city. The organization was the initiator of the Declaration of Children's Rights (also called the Declaration of Geneva), a direct ancestor of the United Nations Convention on the Rights of the Child of 1989. The contribution of the Declaration was to emphasize the issue of child protection at the international level. In her article about the child within the framework of international relations, Dominique Marshall wrote,

\footnotetext{
* Lara Bolzman is an assistant at the Department of Health Studies, University of Applied Sciences of Western Switzerland. The author is a Bachelor and Master of Advanced Studies in History. This article is an extract of a larger research study entitled "Genève au secours de l'enfance en danger. L'oeuvre de l'Union Internationale de Secours aux Enfants, 1920-1945", presented in October 2007 at the University of Geneva to obtain a Masters of Advanced Studies in History. The law is current as of 16 May 2008.

1 The General Assembly adopted the regulation of the League of Nations in Versailles in April 1919, but it was only in January 1920 that it began its activities in Geneva. See P. Mougenot, Atlas historique. De l'apparition de l'homme sur la terre à l'ère atomique, Paris, Perrin, 1990, 413.
} 
“[...] the 'Declaration of Geneva' marked the passing of social work for childhood into an official object of international relations". ${ }^{2}$

In less than one century, protection of the child was transformed from a private concern and brought onto the international stage. This article examines the origin of this important evolution and analyses the key role the SCIU played as an important child protection organization during the interwar period and the Second World War. By analysing the most important work of the Union, the Declaration of Geneva, it also tries to reconstruct the representation of the child at that time, depictions that directly influenced the actions of the organization.

This article is based on a detailed investigation of the archives of the SCIU in Geneva. It also draws on existing literature that used a similar approach, including articles by Dominique Marshall and Jean-Pierre Gaume, concerning the SCIU. ${ }^{3}$

\section{The child's entry onto the international stage}

If the central position given to the child within the context of international relations seems obvious today, this has not always been the case. Before the First World War, a number of governments were against making childhood an object of studies worldwide. This hesitation can partially be explained by the context: before the First World War, there was no event or circumstance that challenged nations to act beyond their boundaries to help hundreds of thousands of young victims. But this hesitation can also be attributed to shifting priorities. Indeed, the protection of the child, originally limited to the private and family context, was in less than one century projected onto the international stage. ${ }^{4}$ Nations and states felt deprived of their know-how and risked losing their control of their youngest citizens, considered from a nationalist perspective as the "lively strengths of the nation". 5

Until the end of the 18th century, in Western societies, the child was above all considered to be part of the private sphere. The protection and well-being of children were considered to be the responsibility of the family and society was not expected to intervene on the matter. From the beginning of the 19th century, the depiction of childhood changed and the child, who thus far had generated little compassion, became a subject of its own rights. The "necessary" or "useful" child became a "precious" being who must be protected and educated. ${ }^{6}$

2 D. Marshall, "The construction of children as an object of international relations: The Declaration of Children's Rights and the Child Welfare Committee of League of Nations, 1900-1924", The International Journal of Children's Rights, Vol. 7, 1999, 103-4.

3 J.-P. Gaume, "L’Union Internationale de Secours aux Enfants", in R. Durant, D. Barbe, and J.-D. Candaux (eds), Gustave Ador. Cinquante-huit ans d'engagement politique et humanitaire, Geneva, Fondation Gustave Ador, 1996, 439-83.

4 F. Thébaud, Quand nos grand-mères donnaient la vie. La maternité en France dans l'entre-deux-guerres, Lyon, Presses universitaires de Lyon, 1986, 14-19.

5 Marshall, "The construction of children as an object of international relations", op. cit., 114.

6 P. Ariès, L'enfant et la vie familiale sous l'Ancien Régime, Paris, Seuil, 1972, 5-6. 
The authority of the "pater familias", until then inescapable, was questioned, notably in view of the strong decrease in the birth rate in Europe at that time. A new perspective on childhood appeared: the child was not only placed under the control of the family, but became a societal object of attention. However, this attention remained local rather than national or international.

The implementation of an "international culture of childhood" was made possible in Europe at the end of the 19th century thanks to the universality of secular elementary schools. ${ }^{7}$ The development of the media facilitated the spread of common standards and values, and contributed to the broadcasting of a common understanding of "culture".

In the 19th century and at the beginning of the 20th century, the widespread dissemination of the notion of a common culture of childhood was also the result of the organization of national and international conferences throughout Europe and the world. These conferences took place at the same time as the World Exhibitions. As with products, ideas must also be presented: "The exhibition displays, the conferences demonstrate, explain, enlighten." ${ }^{8}$ Whether in Paris, London, Brussels, or Geneva, the number of congresses dedicated to child welfare increased in the beginning of the 20th century. Associations and permanent organizations had the task of answering questions raised during these meetings. ${ }^{9}$

However, what really marks the entry of the child onto the international stage was the Declaration of Children's Rights, written in 1923 by the Union and adopted by the General Assembly of the League in 1924.

\section{The establishment of the SCIU: birth of a new type of organization}

In response to the desolation caused by the First World War and influenced by the establishment of the League, numerous charity organizations apart from the SCIU were founded during the interwar period. But the Union asserted itself as a different kind of organization with a unique purpose: to coordinate and to unify all the children's relief actions in Switzerland and around the world. ${ }^{10}$

Within its first few years, the SCIU dedicated itself to children who were victims of armed conflicts. Its first mission was to help war orphans, to feed starving babies, to look after wounded children, and to clothe the underprivileged, either by directly sending food, medical appliances, medicines, etc., or, as in most

C. Rollet, "La santé et la protection de l'enfant vues à travers les congrès internationaux (1880-1920)", Annales de démographie historique, Vol. 1, 2001, 97 (translation by the author).

8 A. Rasmussen, "Les Congrès internationaux liés aux expositions universelles de Paris (1867-1900)", Mil neuf cent: revue d'histoire intellectuelle, Vol. 1, 1989, 26.

9 A. Rasmussen, "Jalons pour une histoire des congrès internationaux au XIX ${ }^{\mathrm{e}}$ siècle: régulation scientifique et propagande intellectuelle", Relations internationales, Vol. 62, 1990, 11.

10 Bulletin de l'Union Internationale de Secours aux Enfant (BUISE), 10-20 January 1920, n 1-2, 6. Archives d'Etat de Genève (AEG), annexe Terrassière, classification mark: A.P. 92.3 .7 (3). 
of the cases, by turning to other organizations already working in the stricken regions and thus more capable of distributing the help. ${ }^{11}$

Other organizations were also working to help young victims of armed conflicts and the Union was quickly obliged to extend its activities. Indeed, the SCIU has defended other causes over time in Switzerland, as well as in Africa, for example. These additional activities notably consisted of proposing measures to educate deprived children and to assist foreigners by providing physical and moral sustenance, etc. However, this "multiplication" of tasks was not fundamentally innovative. Indeed, other organizations also took up additional tasks to guarantee their permanent existence in the absence of massive conflict. It can be argued that from its inception in 1920, the League was determined to add a permanent mission of child protection to its temporary relief activities. ${ }^{12}$ The SCIU thus wanted to be a child relief organization during wartime, while at the same time aspiring to offer permanent assistance to needy children in peacetime.

What was particularly unique and innovative about the Union was the desire of its founders to direct their efforts to the pacification and unification of nations. After the First World War, the world was unanimous on one point: such horrors should never happen again. This will to unite was thus quite naturally well received beyond the borders of Switzerland. In line with this philosophy, the organization ostensibly asserted its neutrality (religious, political, etc.), which was a basic pre-condition for any international collaboration. In reality, the SCIU remained essentially a Christian organization. Although the Comité d'honneur admitted members from other faiths, such as representatives of the Orthodox Church and the Jewish Community, the executive Committee remained in the hands of Christian members.

The Union was convinced that saving the child was equivalent to saving the world. The "moralized" and "saved" child would discover international brotherhood and universal charity and, by this means, it would be possible to implement a new global standard, one of love, forgiveness, and reconciliation. This ambitious vision was spelled out in the following extract of the Report of the 5th session of the SCIU's delegates in 1920: "It is neither peace treaties nor economic activity that will empower the world but it is in the hands of our children that the future of Europe is found." 13

The success of the organization was due not only to its innovative initiatives, such as the Declaration of Children's Rights, but also to its propaganda strategies. To save the child all attempts must be made to emotionally engage the general public, as mentioned in the organization's propaganda sheet of

11 BUISE, 4-6, 1940-41, 122-3. AEG annexe Terrassière, class. mark: A.P. 92.3 .104 (3).

12 P. T. Rooke and R. L. Schnell, “'Uncramping child life': international children's organizations, 1914-1939”, in International Health Organisations and Movements, 1918-1939, Cambridge, New York and Melbourne, Cambridge University Press, 1995, 180.

13 Compte-rendu de la cinquième séance des délégués de l'UISE, Geneva, 8 January 1920, 7. AEG, annexe Terrassière, class. mark: A.P. 92.3 .7 (2). 
March 1920: "we must take hold of the imagination, of sensitive souls, of emotions, of spontaneity, of the natural kindness of women and children; of the spirit of human solidarity, of the social and progressive enthusiasm of the working classes, of national sentiment, of a sense of responsibility, of culture, even of the vanity of the well-to-do classes, etc."14

Finally, the Union also knew how to benefit from a wide network of partners. Some were associated with the feminist movement while others were abolitionist, such as the Quakers. There were other organizations as well, such as the Rockefeller Foundation. The Federal Council of Switzerland was also a close and reliable ally on whom the SCIU could count on during crucial moments, as we will demonstrate in the next section.

\section{The indirect role played by the Swiss Federal Council regarding international child welfare and its relations with the SCIU}

If the role of Swiss authorities does not seem to have been crucial in the development of child protection at a worldwide level, it was nevertheless a very important factor, in a sense a "catalyst". Through the work of the Union, governments became aware of the importance of the child as a "neutral" element in international negotiations.

At the time of the creation of the SCIU in 1920, Gustave Ador had just come to the end of his mandate as president of the Federal Council. As President of the ICRC from 1910 until 1928, he enhanced Switzerland's name in the humanitarian field. As a member of the Comité d'honneur of the Union from its beginnings, he contributed to the excellent reputation of the SCIU's work. ${ }^{15}$ His support was, however, discreet: during the first assembly of the Union, Gustave Ador was not present, and he did not participate in the debates about the patronage of the organization by the ICRC.

Another political figure, Giuseppe Motta, who also played an important role in foreign policy within the Federal Council, was a spokesman for the Union. Elected to the Federal Council in 1912, he first headed the Finance Department before taking charge of the Foreign Affairs Department where he stayed for 20 years. ${ }^{16}$ He was a member of the Comité d'honneur of the Union from the outset. A Bulletin of the SCIU reporting on the activities of the organization from 1920 to 1940 repeatedly underlines the strategic importance of the role played by Giuseppe Motta in favour of the SCIU. In December 1920, he brought forth, in the name of the Swiss Delegation at the Assembly of the League, a proposal to promote means of action in favour of the children. The Bulletin mentions that "by fortunate coincidence, Mr Motta took on the Presidency of the Assembly four years later, when on the 26 September 1924, the Assembly solemnly approved the

14 Feuille de propagande de l'UISE, 20 Mars 1920, op. cit., 4.

15 Gaume, "L’Union Internationale de Secours aux Enfants", op. cit., 471.

16 D. Masmejan, "L'Italophile qui fit entrer la Suisse à la $S D N$ ”, Le Temps, 14 Jul. 2007, available at http:// www.letemps.ch/template/print.asp?article $=211245$. 
Declaration of the Rights of the Child [... . and invited the member states to find inspiration in the work of the protection of the child". ${ }^{17}$

A "coincidence"? Some measure of doubt is permitted! In general, it should be noted that long after Ador and Motta had served their terms at the Federal Council, numerous testimonies in the archives of the SCIU demonstrate the Government's support of the Union's activities.

According to these examples, the State, through powerful and committed intermediaries, made a commitment to save the children. However, the federal State was not the instigator of humanitarian relief. It was happy to remain in the background and to support activities developed by private relief organizations.

The Union maintained ambiguous links with the State. On the one hand, it did not wish to get directly involved with the Confederation, for fear of being controlled, but also because the SCIU, like many philanthropic organizations, did not want the State to intervene in its private affairs. On the other hand, as the Union asserted repeatedly, it could not do anything without the State's support. Such was the price to pay to help the children!

\section{The vision of the child through the Declaration of Geneva}

At the end of the First World War, the Union had one single purpose: to repair the wounds and traumas of the war and unify nations. Benefiting from the momentum of idealism which characterized the SCIU in its first years of existence, the message was clear: there was an imperative to reach out to all children, without distinction as to nationality, religion, etc., as was argued by Romain Rolland, a member of the SCIU, in the Bulletin of the organization of the 15 January 1924: "Victory is only determined by the greatness of one's soul. And the greatest force of all is goodness. We invite all French citizens to extend a helping hand to those people they fought."18

In its early years, the SCIU's dominant message about the child "in need" was that of a poor creature, a victim of conditions imposed by humanity, a victim that must be saved "body and soul", more especially because the child was presented as an isolated human being, deprived of reassuring family or state protection.

This representation of the child is codified in what is certainly the most important work of the Union, the Declaration of Children's Rights. Summed up in five points, these principles put forward a notion of the child to be protected, that is both a "resource" and an isolated "victim".

According to those principles the child is described as being isolated from the family. Indeed, the principles never mention relatives (parents) or family in the broad sense (siblings, extended family, etc.). The child appears separated from its social and national context: the society, the community, and the nation are absent. It appears that because of this isolation, the care and the

17 BUISE, 1 January-March 1940, 9. AEG, annexe Terrassière, class. mark: M.1.3.

18 BUISE, 1, 15 January 1924, 34. AEG, annexe Terrassière, not classified. 


\section{Geneva Declaration of the Rights of the Child (1924)}

I. The child must be given the means requisite for its normal development, both materially and spiritually.

II. The child that is hungry must be fed; the child that is sick must be nursed; the child that is backward must be helped; the delinquant child must be reclaimed; and the orphan and the waif must be sheltered and succoured.

III. The child must be the first to receive relief in times of distress.

IV. The child must be put in a positition to earn a livelihood and must be protected against every form of exploitation.

V. The child must be brought up in the conscience that its talents must be devoted to the service of his fellow-men.

Figure 1. The Declaration of Children's Rights drafted by the SCIU in 1922-3 and adopted by the Assembly of the League in 1924 .

Source: Déclaration de Genève, Geneva, 1923, AEG, annexe Terrassière, class. mark: A.P. 92.3.126.

protection of the youngest must take on a "global" character, encompassing all aspects of the child's life, in both spiritual as well as material terms, as stipulated in the Article I of the Declaration.

The child is also placed at the centre and must, according to Article III, "be the first to receive relief in times of distress", confirming the new priority given to young victims at the global level. Article III puts forward some justifications for the Union's aim of intervening globally: if the innocent child, an isolated victim, is deprived of family and is not defended at the national level, it is the duty of society to intervene to save all children from distress.

SCIU's emblem reinforces this idealistic, almost mystical image of the child: isolated, disembodied, the child is positioned in the centre, alone with arms crossed. Here again we find this idea of the child as an innocent isolated victim and redemptor of the world.

This representation of the child (as isolated, deprived of the support of a family and of a nation and thus unprotected) and the desire to remain a neutral and universal organization significantly influenced the relief actions of the SCIU. The Union was present in occupied regions during the War, such as in the north of France, but the organization also wanted to rescue children belonging to the "losers" camp. Thus, in 1920, Germany, Austria, and Poland were among the countries receiving the greatest subsidies from the SCIU. ${ }^{19}$

In the Declaration of Geneva, the child was also indirectly depicted as a "resource". Given the idea that "the child must be brought up in the conscience that its talents must be devoted to the service of his fellow-men", the authors of the Declaration of Children's Rights briefly touched on the duty of those future adults, "The goal is to give them a taste for work. 'Nothing without labour" ",

19 Secours accordés par l'UISE en 1920, undated, not numbered. AEG, annexe Terrassière, class. mark: A.P. 92.3.44. 
said the members of the Education and Apprenticeship Commission of the IInd International Child Relief Congress. ${ }^{20}$

These examples illustrate the transition from a Malthusian portrayal of the child, where an excess of children was thought to endanger the equilibrium between population and resources, towards a sentimental and utilitarian model of the child. The new model posits that while a child is an innocent creature to be saved it is at the same time a resource to be invested in, to ensure the future of the nation, of humanity. ${ }^{21}$

In addition to the child victim of war, the "normal" child was added to the agenda if the children were "in need". Indeed, Eglantyne Jebb, founder of the organization, "[...] was also aware of the dangers than can threaten even the childhood of so-called 'normal' children". 22 This new actor allowed the Union to be present at the national and international level, independently from the political and social context.

At a time when the notion of the "quality of the race" had become increasingly important, and the power of a nation was measured by its population, attempting "to standardize" the child and guaranteeing its physical, spiritual, and moral development seemed to be an obvious goal. ${ }^{23}$

\section{A new target: the child in moral danger}

Over the years, the tension between idealism and nationalism became more and more perceptible in the speeches and actions of the Union. The SCIU's spirit of universal solidarity was confronted by the increasing importance of the Nations. This tension would continue to grow until the Second World War. In 1933, Hitler's coming to power definitely marked a change in the SCIU's relief actions: all children were still to be saved, but the old dream of unifying all nations seemed very far away.

The Union's discourse, which had been very ambitious up to that time, was subdued into a more pessimistic and less "global" statement: it was no longer a question of feeding the child in "body and mind", but more of giving children "the sympathy they need", as mentioned in the report of the General Secretary, in 1941: "As long as this state of affairs continues, aid work should not waste its energies attempting constructive change. It must simply address physical needs, provide occupations that do not require much effort and give to refugees the sympathy they so desperately need." 24

\footnotetext{
20 "Rapport de la commission d'éducation et d'apprentissage", II Congrès International des Euvres de Secours aux Enfants, Geneva, 7-9 April 1921, 3. AEG, annexe Terrassière, class. mark: A.P. 92.3.20.

21 Rooke and Schnell, “'Uncramping child life': international children’s organizations, 1914-1939”, op. cit., 194.

22 BUISE, 23, 1945, 17. AEG, annexe Terrassière, class. mark: M.1.3.

23 G. Heller, G. Jeanmonod, and J. Gasser, Rejetés, rebelles, mal adaptés. Débat sur l'engénisme. Pratiques de la stérilisation non volontaire en Suisse romande au XX' siècle, Geneva, Georg, 2002, 26.

24 BUISE, 1940-41, op. cit., 142.
} 
This change is partially due to the fact that the child was no longer considered an isolated person: the notion of family began to appear more frequently. Individuals, families, and states were made more and more responsible for the child. This new vision of the child was also presented in the Declaration of Children's Rights when it was revised in 1948 following the Second World War. It reframes the representation of the child once again.

\section{Geneva Declaration of the Rights of the Child (1948)}

I. The child must be protected beyond and above all considerations of race, nationality or creed.

II. The child must be cared for with due respect for the family as an entity

III. The child must be given the means requisite for its normal development, materially, morally and spiritually.

IV. The child that is hungry must be fed; the child that is sick must be nursed; the child that is mentally or physically handicapped must be helped; the maladjusted child must be re-educated; and the orphan and the waif must be sheltered and succoured.

V. The child must be the first to receive relief in time of distress.

VI. The child must enjoy the full benefits provided by social welfare and social security schemes and must receive training which will enable it at the right time to earn a livelihood, and must be protected against every form of exploitation

VII. The child must be brought up in the consciousness that its talents must be devoted to the service of its fellow men.

Figure 2. The Declaration of the Rights of the Child as modified in 1948.

Source: Child Rights Information Network, available at http://www.crin.org/resources/ infoDetail.asp? ID =1309.

These lines testify to the increasing importance given to the social environment of the child, while the notion of family has become apparent (Article II of the Declaration). Although the State is not directly mentioned, it is implicit in the notion of "social security and future investment measures", as stipulated in the Article VI of the Declaration. The concept of "nationality" also appears, as shown in the first article of the statement. The organization's neutrality is also clearly reaffirmed in the first article mentioning the importance of rescuing all children, without consideration of their race or religion. Finally, the issue of material and spiritual development, which was placed at the top of the Declaration in 1924, was now relegated to third place: "global" assistance to the child is no longer uppermost among the Union's concerns. ${ }^{25}$

In numerous bulletins published by the SCIU, failing education and a deficient social environment are put forth as explanations of the conditions that lead children to a dark fate, to suffering, and to moral depravation. ${ }^{26}$ This depiction of the child once again placed the Union in a contradictory position: children are at once both "social capital", in terms of a work force and military force, and at the same time a threat to the law and order of society.

25 If this type of "global" relief, at the same moment physical, moral, and spiritual tends to decrease, it remains still present. Our comment limits to demonstrate that it is maybe not any more the essential purpose of the Union's relief actions.

26 Bulletin de l'UISE et Revue internationale de l'Enfant, Geneva, 1941, 43-7. AEG, annexe Terrassière, not classified. 
An educational intervention for those who got lost could certainly assist in reducing and preventing criminality, but this would mean that the organization would have to take the risk of being "contaminated" by the delinquents and their moral depravation.

In addition, the Union developed an increasingly scientific and rational discourse, which replaced the more emotional tone concerning the child that had dominated until the 1940s. ${ }^{27}$ The SCIU increasingly referenced "experts" of children, such as doctors, psychologists, and social workers. ${ }^{28}$ The legitimacy of the Union's relief actions certainly depended on such references.

However, the organization wanted to reach out beyond interventions for deprived children in post-war times. The SCIU, trying to sustain its actions, also developed a programme of action in Switzerland. In 1941, the organization established a social department in order to work on the question of delinquents and of moral dangers faced during childhood. For this purpose, in the middle of the war emergency, the SCIU published a questionnaire on the legislative reforms needed to address delinquents in Switzerland. The questionnaire was distributed to all the organizations working in the area of child welfare in the country. This document explored the need to create "a social service for children facing moral dangers [...] [and] the need for a police corps specialized in prostitution [...] and delinquencies of minors". ${ }^{29}$

There is no further mention of solidarity or brotherhood and the concept of using the child as a force for unification is no longer identified as a purpose of the organization. It is no longer a time for reconciliation but rather for preserving and repairing what can still be salvaged.

\section{Conclusion}

In the interwar period and during the Second World War the future of the child was at stake. This article shows that the notion of the child and childhood is variable, in constant evolution and (re)construction. What this stage of life represents is a function of society, politics, and organizations and institutions, etc.

Depictions of the child play an important role in relief actions. At times an innocent victim and a symbol of international brotherhood, the child is also subject of hope; sometimes "different", the child then becomes the innocent target of the defects of an entire nation, a child who has to be shown the right way. Sometimes considered a source of "abnormality", the child must be "re-educated" for the future and the well being of the society.

27 Rooke and Schnell, “'Uncramping child life': international children's organizations, 1914-1939”, op. cit., 176.

28 "L'Union Internationale de Secours aux Enfants en 1943-44 et demain", report of the General Secretary, Revue internationale de l'enfant, Vol. III, Geneva, 1944, 34. BPU; class. mark: E 1674 a15.

29 Questionnaire au sujet des réformes à opérer à la législation sur l'enfance en danger moral et délinquante, Geneva, 1941, 1-2. AEG, annexe Terrassière, class. mark: A.P. 92.3.103. 
It is difficult to evaluate the direct contributions of the Union to child welfare. But we can be sure that this organization, by its principles, by its mode of action, and by its strategy, acted as a pioneer in child relief on the international stage. The Declaration of Children's Rights drafted by the SCIU is the most prominent expression of its innovative character and pioneer role. The willingness of the Union to save all children is obvious as it was "the soul of the world" which was to be saved: "We have saved the lives of children, but if we are to remain faithful to this ideal, if we are to do everything in our power to make this ideal happen, we will be able to assist, perhaps, in the task of saving the soul of the world." 30

30 Mémorandum concernant l'Union, Genève, 1929, Annexe B. 14. AEG, annexe Terrassière; class. mark: M.1.2. The author's translation. 